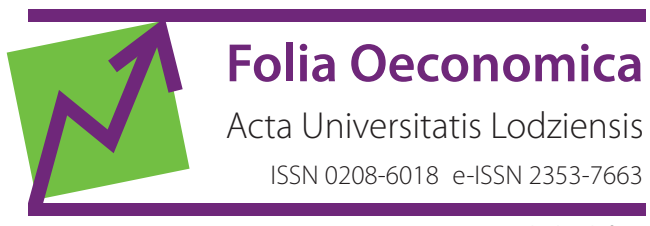

www.czasopisma.uni.lodz.pl/foe/

1(346) 2020

DOI: http://dx.doi.org/10.18778/0208-6018.346.06

\title{
Dagmara Lewicka
}

AGH Akademia Górniczo-Hutnicza w Krakowie, Wydział Zarządzania

Katedra Zarządzania Przedsiębiorstwem, dagal@poczta.fm

\section{Monika Pec}

AGH Akademia Górniczo-Hutnicza w Krakowie, Wydział Zarządzania

Katedra Zarządzania Przedsiębiorstwem, mpelczar@interia.pl

\section{Aleksandra Wilk}

AGH Akademia Górniczo-Hutnicza w Krakowie, Wydział Zarządzania

Katedra Zarządzania Przedsiębiorstwem, aleksandrawilk.contact@gmail.com

\section{Motywy podejmowania organizacyjnych zachowań obywatelskich przez zróżnicowane pokoleniowo grupy pracowników}

Streszczenie: Problematyka podejmowania organizacyjnych zachowań obywatelskich (OCB) w przedsiębiorstwach, ze względu na ich szeroki i pozytywny wpływ na wiele aspektów działalności organizacyjnej, pozostaje w obszarze zainteresowań teoretyków i praktyków zarządzania. Zachowania te, wychodzące poza formalną rolę zawodową pracowników, wpływają na jakość wykonywanej pracy, efektywność finansową, poprawiają atmosferę pracy, stymulują rozwój kompetencji i zachowań innowacyjnych oraz zadowolenie klientów. Nie w pełni zidentyfikowane pozostają jednak determinanty i uwarunkowania, w których pracownicy działają dla dobra organizacji, nie oczekując za to wynagrodzenia. Celem niniejszego artykułu jest identyfikacja i analiza motywów podejmowania zachowań obywatelskich przez przedstawicieli grup pracowniczych zróżnicowanych pokoleniowo. Eksploracyjny charakter problemu przesądził o przyjęciu postępowania jakościowego. W opracowaniu wykorzystano metodę studium przypadku, a w jej ramach wywiady częściowo ustrukturyzowane oraz analizę dokumentów firmy.

Słowa kluczowe: organizacyjne zachowania obywatelskie, pokolenia pracowników

JEL: M14 


\section{Wprowadzenie}

Zachowania obywatelskie są przedmiotem badań naukowych od ponad czterdziestu lat (Turek, Czaplińska, 2014). Definiowane są jako:

[...] indywidualne zachowania podejmowane dobrowolnie, niebędące w sposób bezpośredni lub wyraźny ujmowane w formalnym systemie nagradzania pracowników, a które łącznie sprzyjają skutecznemu i efektywnemu funkcjonowaniu organizacji (Organ, Podsakoff, MacKenzie, 2006: 3).

Wyróżniono siedem kategorii ${ }^{1}$ zachowań obywatelskich opisanych przez Organa $^{2}$ (Turek, 2013: 29-30).

W literaturze przedmiotu wskazuje się, że OCB wpływają na produktywność pracowników, sprawność kierowania organizacją, poziom pracy zespołowej i kooperacji, poziom reputacji przedsiębiorstwa, elastyczność organizacji i zdolność dostosowywania się do zmian (Organ, Podsakoff, MacKenzie, 2006: 200-202), efektywność i relacje z klientami (Podsakoff i wsp., 2009), budowanie pozytywnej marki wśród konsumentów (Fowler, 2013: 4-5) czy wzmacnianie spójności zespołu (Chen, Tang, Wang, 2009: 638). Korzyści z podejmowania zachowań obywatelskich wykraczających poza organizację mogą skutkować pozytywnymi zmianami w lokalnym, a nawet globalnym kontekście (Cohen, Vigoda, 2000: 599). Także sami pracownicy odczuwają pozytywne aspekty podejmowania tego typu zachowań - ze względu na to, że w ich wyniku zwiększa się ich satysfakcja z pracy, zaangażowanie i lojalność wobec przedsiębiorstwa (Punjaisri, Wilson, 2007: 67). Pozytywny aspekt podejmowania OCB wpływa na zakwalifikowanie tej koncepcji do nurtu zjawisk i procesów organizacyjnych związanych z Positive Organizational Scholarship (Glińska-Neweś, Lis, 2016: 266).

Tematyka zachowań obywatelskich podejmowana jest przez badaczy w wielu kontekstach. Autorzy poruszają między innymi takie kwestie jak: wpływ OCB na organizację i współpracowników (Bommer, Miles, Grover, 2003; Chen, Tang, Wang, 2009; Lin i wsp., 2010), aspekt społeczny lub relacyjny tych zachowań (Spence i wsp., 2011), odkrywanie ich „ciemnych stron” (Vigoda-Gadot, 2006; Bolino i wsp., 2013) czy identyfikację motywów ich podejmowania (Blatt, 2008). Blatt (2008) zidentyfikował cztery mechanizmy, które mogą leżeć u podłoża podejmowania zachowań OCB: mechanizm wymiany (opisany w ramach teorii wymiany społecznej), mechanizm identyfikacji, a także działań związanych z kreowaniem wizerunku oraz kształtowania relacji z kierownictwem i pracownikami. Dotychczasowe badania poświęco-

1 Siedem kategorii zachowań obywatelskich: pomaganie innym, wytrwałość/wyrozumiałość, lojalność organizacyjna, posłuszeństwo organizacyjne, inicjatywa, cnoty obywatelskie, samorozwój.

2 W literaturze przedstawiono szerszą klasyfikację zachowań obywatelskich przejawianych przez pracowników (Chwalibóg 2013). 
ne uwarunkowaniom i determinantom zachowań obywatelskich wskazują między innymi, że zachowania te są silnie zależne od dyspozycji jednostki (tzn. osobowości, emocji) (Greguras, Diefendorff, 2010: 551; Gore, Kiefner, Combs, 2012: 2438), postaw pracowników (Cohen, 2006), postrzegania organizacji (Fassina, Jones, Uggerslev, 2008) oraz oceny jej funkcjonowania (Britt i wsp., 2012), a także stylu kierowania przełożonych (Organ, Podsakoff, MacKenzie, 2006: 95-109). Na polskim gruncie naukowym temat ten jak dotąd nie był szeroko eksplorowany przez badaczy. W związku $\mathrm{z}$ tym celem przestawionych $\mathrm{w}$ artykule rozważań jest identyfikacja i analiza motywów zachowań obywatelskich podejmowanych przez przedstawicieli grup pracowniczych zróżnicowanych pokoleniowo, zatrudnionych w wybranej firmie handlowej. Autorki niniejszego opracowania podjęły próbę uzyskania odpowiedzi na pytanie, czy zróżnicowani wiekowo pracownicy kierują się różnymi przesłankami, podejmując działania wykraczające poza ich formalne obowiązki wynikające ze stosunku pracy.

\section{Motywy podejmowania zachowań obywatelskich}

Jak wspomniano we wprowadzeniu, powody, dla których pracownicy przejawiają zachowania obywatelskie, mogą być zróżnicowane. Niektórzy badacze sugerują, że prawdziwy motyw (poza wymiarem prospołecznym) ma charakter „polityczny” lub nakierowany jest na kształtowanie wizerunku pracownika w otoczeniu (tzw. impression management) w celu zwiększenia swoich szans zawodowych lub zdobycia premii (Snell, Wong, 2007; Yun, Takeuchi, Liu, 2007; Grant, Mayer, 2009). Mimo iż ani organizacja, ani przełożeni de facto nie wymagają takich zachowań, zdarza się, że pracownicy są z nich rozliczani podczas oceny lub awansów (Bolino i wsp., 2013). W związku z tym zjawiskiem sformułowany został termin poszerzanie obowiązków zawodowych (extending professional duties), mówiący o dodatkowych wymaganiach, które nie zostały pierwotnie ujęte w opisie stanowiska pracy, a są egzekwowane od pracowników przez kadrę kierowniczą (Van Dyne, Ellis, 2004: 181; Vigoda-Gadot, 2006). Chcąc sprostać nieformalnym wymaganiom, zatrudnieni podejmujący OCB mogą być narażeni na brak akceptacji swojej postawy ze strony kolegów i uznani za „wychodzących przed szereg”, a wszelkie inicjatywy mogą być odbierane jako próby przypodobania się kierownictwu, a nawet obnażenia biernej postawy współpracowników (Spence i wsp., 2011: 547-553). Brak dobrowolnego charakteru OCB może być zatem spowodowany oczekiwaniami lub nawet presją (citizenship pressure), którą odczuwają zatrudnieni (Bolino i wsp., 2010). Warto jednak mieć na uwadze to, że zachowania obywatelskie mogą mieć negatywny wydźwięk tylko wtedy, kiedy nie są dobrowolnymi inicjatywami pracowników, kiedy są one niskiej jakości lub mają zastępować zachowania wynikające z zajmowanego stanowiska. W takiej sytuacji istnieje zagrożenie, że mogą w sposób niepożądany wpływać na wizerunek i efektywność organizacji (Bolino i wsp., 2013: 2). 


\section{Pokolenia pracowników podejmujących zachowania obywatelskie}

Obecnie na rynku pracy przeważającą część zatrudnionych stanowią przedstawiciele pokoleń $\mathrm{X}$ oraz $\mathrm{Y}$. Każdego roku, z powodu przejścia na emeryturę, liczba pracowników urodzonych w latach 1946-1964 staje się coraz mniejsza. Ich miejsce zajmują młodzi ludzie generacji Z, którzy po zakończeniu edukacji wkraczają na ścieżkę zawodową. Klasyfikacja generacji oparta jest zazwyczaj na przyjętym przez poszczególnych autorów podejściu oraz uwarunkowaniach krajów, w których prowadzone są badania. Najczęściej w literaturze wymieniane są cztery generacje (Robbins, Judge, 2011; Fenney, 2012; Rusak, 2013):

1) pokolenie powojennego wyżu demograficznego (baby boomers) - z lat 1946-1964,

2) pokolenie X (baby busters) - urodzeni w latach 1965-1980,

3) pokolenie Y (millennials) - $\mathrm{z}$ lat 1980-1994,

4) pokolenie Z (connected, iGeneration) - urodzeni w roku 1995 i później.

Każde $\mathrm{z}$ wymienionych pokoleń wzrastało $\mathrm{w}$ innych warunkach gospodarczych, społecznych i kulturowych. Kształcone było w odmiennych modelach edukacji i miało różne autorytety. Różnice te ukształtowały charakterystyczne dla każdej generacji oczekiwania i zachowania. Przedstawiciele powojennego wyżu demograficznego przykładają większą uwagę do potrzeb indywidualnych, są bardziej skoncentrowani na sobie (ale cenią pracę zespołową), przejawiają większą skłonność do wydawania pieniędzy i czerpania przyjemności z życia. Pokolenie $X$ jest postrzegane jako najlepiej odnajdujące się w tzw. wyścigu szczurów - ze względu na skupienie na karierze wyznaczanej przez własną ambicję i dążenie do osiągnięcia wysokiego statusu społecznego. Ponadto reprezentantów tego pokolenia uważa się za podatnych na bodźce motywacyjne, takie jak: podwyżka, awans, władza i wpływy. Pokolenie Y, w odróżnieniu od wcześniejszych generacji, oswoiło nowinki technologiczne i aktywnie korzysta z mediów i technologii cyfrowych. Za sprawą roszczeniowego podejścia w pracy oraz wymagań, które nie zawsze są współmierne z posiadanymi umiejętnościami, uznawane jest za generację ,zuchwałą”. Jest to częściowo spowodowane wychowaniem w przeświadczeniu, że są „kowalami własnego losu”, a częściowo poczuciem wolności i niezależności, jakie daje korzystanie z technologii informacyjnych. Generacja $\mathrm{Z}$ dopiero wchodzi na rynek pracy, w związku z tym nie została jeszcze do końca rozpoznana i opisana. Wydaje się jednak, że jej wyznacznikami są doświadczenie i eksperyment. Młodzi ludzie z generacji $Z$ nie są nastawieni na stabilizację. Są odporni na klasyczne bodźce motywacyjne. W pracy poszukują możliwości rozwoju, ciekawych projektów, różnorodności, a za ich mocną stronę uznaje się wielozadaniowość i podzielność uwagi (Aniszewska, 2015: 3-6). 
Na Rysunku 1 przedstawiono uwarunkowania procesu podejmowania zachowań obywatelskich przez pracowników. Zróżnicowane pokoleniowo osoby inicjują OCB, które mogą spotkać się z negatywną bądź pozytywną reakcją organizacji. Negatywna reakcja prowadzi do zniechęcenia pracowników i zaprzestania podejmowania zachowań obywatelskich. Pozytywna reakcja może przynieść wiele korzyści zarówno dla organizacji (m.in. lojalność, satysfakcję, zaangażowanie pracowników, pozytywny wizerunek i reputację), jak i jej otoczenia (relacje z interesariuszami, zmiany w społeczności lokalnej). Niestety, podejmowanie OCB, mimo pozytywnej reakcji organizacji, może mieć także „ciemną stronę”. Jej przejawy dostrzegalne są na przykład w skupieniu się jedynie na kształtowaniu własnego wizerunku, relacjach między współpracownikami, wzajemnej wrogości czy rywalizacji, a w relacjach na linii przełożony-podwładny między innymi w nieformalnym egzekwowaniu OCB.

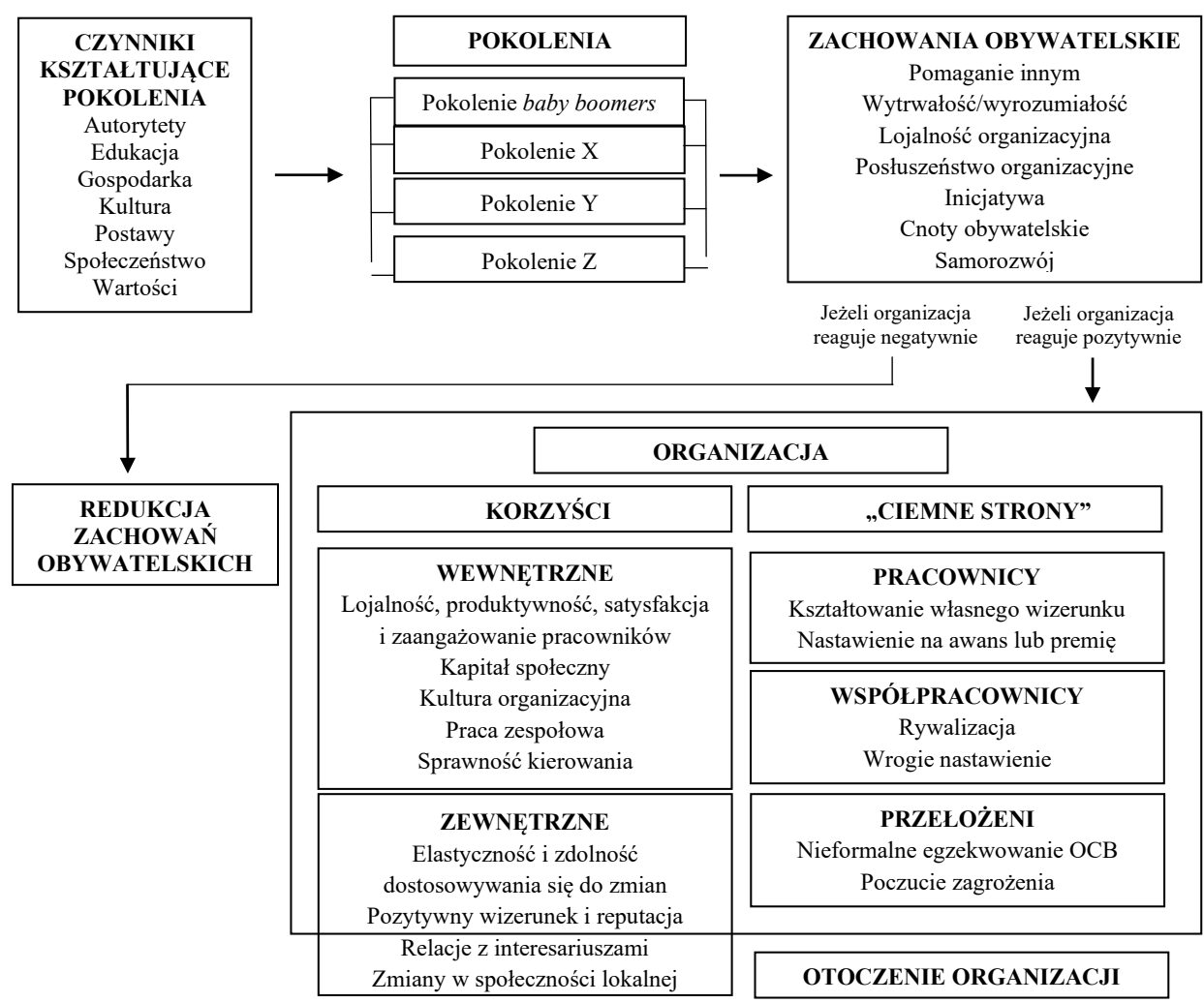

Rysunek 1. Podejmowanie zachowań obywatelskich przez pracowników

Źródło: opracowanie własne na podstawie: Vigoda-Gadot, 2006; Snell, Wong, 2007; Grant, Mayer, 2009; Spence i wsp., 2011; Bolino i wsp., 2013 


\section{Metodyka badania}

Celem badania była identyfikacja i analiza determinantów OCB wśród zróżnicowanych wiekowo pracowników w firmie handlowej, stanowiącej filię przedsiębiorstwa transnarodowego. O wyborze przedsiębiorstwa jako podmiotu badania zadecydowały przede wszystkim: deklarowana przez nie realizacja polityki personalnej wspierającej różnego rodzaju inicjatywy i aktywności pracownicze oraz kultura organizacyjna promująca wartości - empowerment (wzmocnienie), odwagę i postawy proaktywne ${ }^{3}$. Również wspieranie różnorodności, w tym ze względu na wiek, stanowi ważny element kultury organizacyjnej firmy ${ }^{4}$.

W ramach realizacji celu głównego zidentyfikowano kilka celów szczegółowych, w ramach których starano się zidentyfikować: postrzeganie OCB przez zróżnicowanych pokoleniowo pracowników, postawy pracowników wobec OCB, motywy podejmowania OCB, czynniki wpływające na chęć lub brak chęci podejmowania OCB, wpływ OCB na rozwój kariery zawodowej, konsekwencje podejmowania OCB przez pracowników oraz niedogodności mogące towarzyszyć podejmowaniu OCB.

Badanie zrealizowano we wrześniu 2018 roku w siedzibie przedsiębiorstwa. W opracowaniu wykorzystano metodę studium przypadku, a w jej ramach wywiady częściowo ustrukturyzowane oraz analizę dokumentów firmy. Uznano, że taka forma zebrania materiału może pokazać pogłębiony obraz sytuacji, który byłby trudny do uchwycenia w badaniu ilościowym. Autorki przeprowadziły wywiady na podstawie opracowanych zgodnie z celami badania dyspozycji do wywiadu. Każda sesja trwała około 20 minut (najkrótszy wywiad 15, najdłuższy 25 minut). Przebieg wywiadów był nagrywany za zgodą uczestników. Uzyskane dane poddano analizie metodą kodowania spisanego tekstu wywiadów (transkrypcji). W miarę postępowania procesu starano się przypisać kody poszczególnym wypowiedziom, które w kolejnych etapach miały posłużyć wyprowadzeniu wniosków i realizacji celu głównego oraz celów szczegółowych. W przedstawionym materiale empirycznym umieszczono również wybrane cytaty z przeprowadzonych wywiadów. W badaniach tego typu ważne jest, aby

3 W opisywanym przedsiębiorstwie tzw. dobre praktyki są nagradzane w organizowanym corocznie konkursie. Konkurs ma zasięg instytucjonalny, jawny charakter i duże wsparcie ze strony zarządu. O wygranych rozstrzyga komisja powołana przez zarząd, złożona z przedstawicieli wszystkich działów firmy. W ten sposób doceniane są najlepsze inicjatywy oraz zasłużeni pracownicy. Nagrody przyznawane są między innymi za zrealizowanie interesujących projektów i wdrożenie nowatorskich udogodnień. Wyróżnia się pracowników wykazujących w pracy inicjatywę, zgłaszających pomysły, angażujących się w podnoszenie kwalifikacji osób nowo zatrudnionych.

4 Przedsiębiorstwo może poszczycić się dużym zróżnicowaniem wiekowym pracowników. Osoby, które rozpoczęły współprace z firmą ponad 25 lat temu, do dzisiaj stanowią około $35 \%$ zatrudnionych. 
opisać problem w sposób jak najbardziej rzetelny, dopuścić do głosu samych badanych, których wypowiedzi naukowo umacniają tekst i pozwalają na wyrażenie osobistego doświadczenia (Kostera, 2003: 27).

Badaniem zostało objętych 12 pracowników w przedziale wiekowym od 23 do 65 lat, pochodzących z czterech generacji. Troje reprezentowało pokolenie baby boomers, troje baby busters, czworo millennials, a dwoje iGeneration. Respondenci pochodzili zarówno z działów sprzedażowych, jak i wspierających sprzedaż (wsparcie sprzedaży, biuro obsługi klienta, dział personalny, serwis, marketing).

\section{Wyniki badań}

\subsection{Czynniki warunkujące OCB}

W celu wzbudzenia motywacji respondenta do udzielania szczerych odpowiedzi część pytań do wywiadu została skonstruowana w taki sposób, że początkowo ich forma sugerowała pozyskanie informacji dotyczących ogółu pracowników, a w kolejnej fazie nakierowana była na sytuację samego respondenta. Osoby badane, udzielając odpowiedzi w pierwszej fazie wywiadu, wyrażały swoje zdanie na temat zachowań i postaw kolegów, a następnie odnosiły je do własnej osoby.

Badanych zapytano o podejmowanie przez pracowników przedsiębiorstwa zachowań, które nie są wynagradzane i bezpośrednio wpisane w formalny kontrakt zawodowy. Mimo iż wszyscy $(n=12)$ przyznali, że podejmują takie zachowania, ich wypowiedzi zazwyczaj kończyły zdania typu: „Tak [...], ale nie do końca musi to być bezinteresowne działanie, w głębi duszy liczą na docenienie”; „Ostatecznie pretendują do nagrody, licząc na uznanie, premię czy wyższe wynagrodzenie”.

Zapytani o determinanty podejmowania OCB wskazywali zróżnicowane ich motywy - „Pracownicy są skrajnie różni, ile ludzi tyle powodów [...]”:

1) wewnętrzną potrzebę pomagania innym, zdaniem respondentów wynikającą z osobowości, potrzeb, wychowania, wyznawanych wartości: „Załatwiłam sprzęt dla schroniska, po prostu pomaganie zwierzętom leży mi na sercu";

2) wspólne podejmowanie działań: „Są ludzie, którzy potrafią się zjednoczyć, dobrze się czują w swoim towarzystwie. Są możliwości ku temu - i finansowe, i innego typu, żeby coś takiego zorganizować, i to też jest jakaś dodatkowa motywacja do pracy";

3) dobre samopoczucie jako rezultat OCB: „A może ktoś ma lekkie ADHD i nie potrafi usiedzieć na miejscu i to się przekłada na takie działania”; „Satysfakcja, uznanie [...]";

4) prestiż, zaspokojenie potrzeby uznania, chęć otrzymania nagrody, awansu: „Jedni mogą liczyć na awans, drudzy mogą liczyć na dodatkowe korzyści finansowe, inni robią to, żeby się pokazać, polepszyć wizerunek"; 
5) nabywanie nowych umiejętności: „OCB rozwijają kreatywność, sposób myślenia, sposób działania, co może pomóc także w relacjach z klientami”;

6) wsparcie dla realizacji celów prywatnych: „Koleżanka zaangażowała się mocno w udział pracowników naszej firmy w bieg uliczny, którego dochód przeznaczony miał być na protezy dla ludzi po amputacjach, ponieważ jej ojciec stracił nogę. To było takie szlachetne działanie, ona zmobilizowała do maratonu wiele osób z firmy";

7) podłoże polityczne: „Pracownicy zgłaszają swój udział w projektach tylko w celu zauważenia ich nazwiska przez zarząd, po czym w projektach nie biorą udziału”; „Pamiętam akcję wsparcia dla dzieci z domu dziecka zorganizowaną pierwotnie bezinteresownie przez pracowników jako akt pomocy względem innych, a w ostatecznym rozrachunku zgłoszonej przez tych samych pracowników do konkursu pracowniczego celem wygrania wysokiej nagrody pieniężnej - $20000 \mathrm{zl}$ ”.

Zdaniem respondentów $(n=12)$ tego rodzaju zachowania są najczęściej związane $\mathrm{z}$ wewnętrznymi charakterystykami jednostki i determinowane przez osobowość, wyznawane wartości i postawy (np. altruizm, życzliwość). W opinii uczestników $(n=11)$ satysfakcja z pracy i zaangażowanie w nią wpływają na chęć podejmowania OCB: „OCB są efektem dobrej atmosfery w pracy, generalnie zadowolenia i satysfakcji z pracy".

Respondenci podkreślali, że podejmowanie zachowań obywatelskich jest związane z aktywnością jednostki oraz potrzebą autonomicznego działania i sprawdzania się w nim: „To osoby aktywne, podejmują dodatkowy wysiłek wychodzący poza ich ścisłe obowiązki i zazwyczaj osiągają sukcesy zawodowe”; ,Jeśli jestem niezadowolony z pracy, to podejmuję dodatkowy wysiłek, żeby dostać np. awans i być zadowolonym, a jeśli jestem zadowolony, to też podejmuję dodatkowy wysiłek". Warto zaznaczyć, że rozumienie OCB w ten sposób jest zgodne z teorią autodeterminacji Deciego i Ryana (2000), która postrzega człowieka jako aktywny system mający potencjał do działania, samorozwoju i integrowania swojego funkcjonowania. Dobrostan człowieka zależy od tego, w jaki sposób może on realizować potrzeby we własnym środowisku. Autorzy niniejszej teorii skupili się na trzech najważniejszych potrzebach: rozwoju kompetencji, autonomii i relacji, które mogą być realizowane przez pracowników w ramach działań OCB.

Respondenci zapytani o to, czy pracownicy z ugruntowaną, silną pozycją w organizacji nadal byliby zainteresowani podejmowaniem zachowań obywatelskich, odpowiadali $(n=10)$, że częstotliwość podejmowania OCB spada wraz z wyższym zaszeregowaniem w hierarchii: „Jeżeli pracownik wewnętrznie odczuwa taką potrzebę, to czemu nie. Oczywiście rzadko, bo żyjemy w bardzo materialnym świecie. Jest grupa ludzi, którzy są wysoko, a i tak chcą coś robić, ale to jest wąska grupa". 


\subsection{Reakcja organizacji na zachowania OCB}

Podczas badania respondenci zostali zapytani o stosunek przełożonych, współpracowników i organizacji do OCB. W opinii respondentów współpracownicy różnie odnoszą się do akcji i inicjatyw wpisujących się w ramy organizacyjnych zachowań obywatelskich: „Jedni się śmieją, inni dopingują, a jeszcze inni są obojętni, wszystko zależy od osoby". Ogólnie reakcje te można scharakteryzować w czterech obszarach:

1) wzajemności - badani $(n=10)$ czują powinność odwdzięczania się innym za podejmowanie w stosunku do nich OCB; respondenci tłumaczyli, że wkład włożony w postaci troski i zainteresowania sytuacją współpracowników, oferowanej pomocy, dzielenia się wiedzą zostaje oddany na podobnym poziomie; wniosek ten jest zgodny z teorią wymiany społecznej i stanowi wsparcie merytoryczne dla działań mających na celu inicjowanie pomocy we wzajemnych relacjach (Cropanzano, Mitchell, 2005);

2) docenienia - w opinii uczestników $(n=8)$ organizacja docenia podejmowanie OCB, ale odbywa się to w sposób niejasny, nietransparentny, bez zachowania jednolitych standardów; respondenci tłumaczyli, że kwestia ta nie została uregulowana przez organizację, czego skutkiem jest to, że: „Niektórzy przełożeni doceniają bardziej, inni mniej, a jeszcze inni wcale”5; ,Jedni przełożeni nagradzają dodatkową nagrodą na koniec roku swoich pracowników, a w niektórych działach pracownicy nie mają nawet wiedzy, że takie nagrody przełożony może przyznać";

3) negatywnych reakcji przełożonych - według badanych $(n=4)$ organizacja nie docenia dodatkowego wysiłku, a podejmowanie OCB miało negatywny wpływ na rozwój ich kariery zawodowej; respondenci tłumaczyli, że ich przełożeni nie akceptują ,,wychodzenia przed szereg”: „Firma może promować albo blokować. Moja blokuje i to skuteczne, zabija mój zapał, a potem ja zabijam zapał innych”; „Oduczono mnie tego. Każda postawa prospołeczna spotykała się z jakąś dezaprobatą, bo nie była po linii własnych korzyści przełożonych”; „Przez OCB pracownik buduje własną pozycję, inne postrzeganie przez pracowników. Żaden przełożony nie lubi silnej osobowości poniżej swojego stanowiska. Chce, żeby ktoś na niego pracował, na jego wizerunek. Jeżeli nie pracujesz na przełożonego, to przełożony nie świeci”; „Przełożony nie lubi indywidualności”; „Pracownicy podnoszą prestiż, ale nie tylko swój własny, cała organizacja na tym zyskuje, czasem tylko bezpośredni przełożeni tego nie rozumieją. Może czują się po prostu zagrożeni”; wskazywano także na nieformalne egzekwowanie OCB: ,Jeden z przełożonych źle ocenił pod-

$5 \quad$ W badanym przedsiębiorstwie na poziomie działowym przyznawane są także pieniężne nagrody o charakterze uznaniowym, jednakże mają one z reguły charakter niejawny. 
władnego podczas oceny rocznej, uzasadniając ocenę niepodejmowaniem żadnych inicjatyw przez tego pracownika"; odnotowano wypowiedzi wskazujące na akty manipulacji, kiedy osoby wyżej postawione w hierarchii przypisywały sobie inicjatywy podejmowane przez pracowników: „Koleżanka przedstawiła nieswój projekt jako swój przed całą firmą i to było smutne, zresztą wiele takich inicjatyw, np. Szlachetna Paczka czy piknik rodzinny połączony z koncertem charytatywnym organizowany w naszej firmie, miało wielu ojców odpowiedzialnych za sukces przedsięwzięcia”, czy pogardę: „Pracownicy nie są jednolicie traktowani, jedni gardzą OCB, inni wręcz przeciwnie”;

4) sprawiedliwości - kilku badanych $(n=4)$ odniosło się do relacji poczucia sprawiedliwości w związku z OCB; wskazywali oni, że w związku z brakiem jednolitych zasad przełożeni różnych działów tej samej organizacji wykazywali różny stosunek do OCB, a „Konsekwencją takich zachowań jest poczucie, że nie ma sprawiedliwości w firmie”; w ich opinii, jeśli istnieją wyraźne różnice w sposobie postrzegania i odnoszenia się do zachowań obywatelskich, obniża się poziom poczucia sprawiedliwości pracowników; jest to zgodne z teorią sprawiedliwego nagradzania Adamsa (Lewicka, Wiernek, 2004); jeśli pracownicy uważają, że ich dobrowolny wysiłek podejmowany w zakresie działań obywatelskich jest niedostatecznie nagradzany w porównaniu ze współpracownikami wkładającymi wysiłek na podobnym poziomie, może pojawić się poczucie niesprawiedliwości i w efekcie skłonność do zaprzestania tego typu działań; część ankietowanych $(n=9)$ podkreślała, że jeśli nie mogłaby liczyć na wsparcie organizacji, podejmowałaby takie zachowania na poziomie jednostkowym (w stosunku do kolegów i koleżanek) i ewentualnie na poziomie działowym.

\subsection{Wiek a podejmowanie OCB}

Uczestnicy badania odpowiadali w zróżnicowany sposób na pytanie o to, jak wiek pracownika wpływa na chęć lub brak chęci do podejmowania OCB. W opinii pierwszej grupy respondentów $(n=4)$ z wiekiem pracownicy wykazują mniejszą chęć do podejmowania OCB. Rozmówcy tłumaczyli to zjawisko innymi niż rozwój zawodowy priorytetami w życiu, na przykład obowiązkami w stosunku do rodziny, brakiem zachęt ze strony organizacji, doświadczaniem przez lata pracy braku wsparcia ze strony organizacji i przełożonych, a nawet jawnym zniechęcaniem do OCB: „Starszy, jeśli ma złe doświadczenie, wie, że takie zachowania nie mają sensu, a młody jeszcze nie wie, więc próbuje wszystkiego”; „Nie spotkałem się, żeby ktoś po roku pracy usiłował jeszcze podjąć jakąś akcję”, „Ludzie starsi są już pogodzeni, ludzie młodzi szukają swojej ścieżki, a nowy projekt jest szansą na jej znalezienie, poza tym mają potrzebę zmian". W opinii kolejnej grupy $(n=4)$ zależ- 
ność między OCB a wiekiem jest zupełnie odwrotna, to starsi pracownicy chętniej podejmują $\mathrm{OCB}$, pomagają innym, ponieważ młodsza generacja z reguły skoncentrowana jest na swoich sprawach: „Pomimo iż starsi z reguły mają mniej energii, mają doświadczenie. Młode pokolenie jest bardziej interesowne, są skoncentrowani na swoim prywatnym życiu, pasjach, hobby, a dla starszych ważne są relacje, kontakty międzyludzkie, pomoc innym”; „Starsi są doskonali w tego typu akcjach, działają prężnie w firmach, uniwersytetach III wieku czy kołach wiejskich, potrafią robić niebywałe rzeczy". Według ostatniej grupy $(n=4)$ wiek nie jest zmienną wywierającą wpływ na OCB. Warto jednak zaznaczyć, że w trzech wyżej wyszczególnionych grupach odpowiedzi wśród respondentów nie zauważono wyrazistego zróżnicowania ze względu na wiek.

Na uwagę zasługuje fakt, że przedstawiciele najmłodszych generacji - Y i Z - jako najważniejsze i najczęściej podejmowane działanie OCB wskazywali samorozwój, a w drugiej kolejności pomoc koleżeńską: „Rozwój własny jest priorytetowy, no i jeszcze pomaganie koledze w pracy. Może kiedyś ja będę potrzebował pomocy. Tylko trzeba wybadać, komu się pomaga". Oczekiwanie rewanżu w wyniku udzielenia pomocy należy jednak zakwalifikować do zachowań manipulacyjnych, bazujących na automatyzmie wpływu społecznego - regule wzajemności (Cialdini, 2013).

\section{Podsumowanie}

Przedstawione wyniki badań pokazują, że za podejmowaniem przez pracowników OCB stoją różne motywy. Respondenci jako uwarunkowania wpływające na wyzwalanie zachowań OCB wskazywali zarówno na czynniki osobowościowe (podmiotowe), jak i sytuacyjne czy środowiskowe, związane z reakcją otoczenia lub jej brakiem. Wszyscy respondenci twierdzili, że wpływ na skłonność do podejmowania lub niepodejmowania zachowań OCB mają: osobowość, wyznawane wartości i postawy, co jest zbieżne z badaniami innych autorów (np. Cohen, 2006; Greguras, Diefendorff, 2010; Gore, Kiefner, Combs, 2012). Zdaniem wszystkich uczestników badania zachowania OCB mogą poprawiać wizerunek pracownika, zwiększać szansę na awans lub dodatkową premię, dlatego nie są podejmowane zupełnie bezinteresownie. Wniosek ten pojawia się również w badaniach innych autorów (m.in. Snell, Wong, 2007; Grant, Mayer, 2009).

Wypowiedzi badanych wskazują także, że zachowania obywatelskie mogą być warunkowane występowaniem kilku motywów równocześnie. Zaznaczyć należy, że motywy mogą ulegać zmianom w trakcie prowadzonych działań, na przykład pod wpływem czynników sytuacyjnych. W przypadku braku wsparcia ze strony organizacji pracownicy uważają, że byliby skłonni podejmować zachowania OCB tylko w relacjach horyzontalnych - w stosunku do kolegów i koleżanek. Wnio- 
sek ten odpowiada między innymi ustaleniom S. W. Whitinga, P. M. Podsakoffa i J.R. Pierce'a (2008) oraz L. Van Dyne i J.A. LePine'a (1998), wskazującym na potrzebę rozpatrywania OCB w dwóch płaszczyznach: organizacyjnej - tzw. zachowania nastawione na organizację (OCB-Organisation) i indywidualnej - zachowania nastawione na ludzi (OCB-Invidual). Rozróżnienie to wynika z odmienności motywów jednostek, ich uwarunkowań i skutków, do których prowadzą. Jeśli przełożeni nie są skłonni do stwarzania warunków wspierających OCB, dobrze byłoby, gdyby przynajmniej zachowywali neutralne postawy:, ,...] przynajmniej nie przeszkadzać". $Z$ deklaracji respondentów wynika bowiem, że nawet bez takiego wsparcia część z nich nadal podejmowałaby OCB. Można wnioskować, że jeśli wsparcie przełożonych będzie odczuwalne, pracownicy będą wykazywać większą gotowość do zachowań obywatelskich.

Warto zaznaczyć, że respondenci jako najważniejszy i najczęściej podejmowany rodzaj OCB wymieniali samorozwój i pomaganie innym w nadziei rewanżu za okazaną pomoc. Może to wskazywać, że tak naprawdę koncentrują się oni w pierwszej kolejności na sobie i swoich potrzebach, a nie na potrzebach organizacji czy kolegów i koleżanek.

Ograniczenia przedstawionego badania związane są z przyjętą metodyką, która skupia się na wyjaśnianiu badanych zjawisk, równocześnie nie dając rozstrzygających odpowiedzi na postawione pytanie. Badania tego typu nie umożliwiają dokonywania uogólnień, a jedynie wnioskowanie dotyczące badanej próby. Ponadto należy podkreślić, że opinie wyrażane przez respondentów mogą być zniekształcone przez selektywne, tendencyjne postrzeganie czy też błędy atrybucji. Warto jednak zauważyć, że wyniki niniejszych analiz mogą być potraktowane jako punkt wyjścia do przeprowadzenia badań ilościowych na reprezentatywnej próbie respondentów.

W dalszej eksploracji warto byłoby uwzględnić wpływ innych zmiennych, mogących warunkować skłonność do podejmowania OCB, na przykład stażu pracy w danej organizacji, płci, rodzaju i wielkości podmiotu. Interesujące byłoby także zbadanie oddziaływania systemu ZZL na stymulowanie zachowań obywatelskich.

\section{Bibliografia}

Aniszewska G. (2015), Zmiany pokoleniowe a decyzje i wybory konsumenckie, „Marketing i Rynek”, nr 1(22), s. 2-7.

Blatt R. (2008), Organizational citizenship behavior of temporary knowledge employees, „Organization Studies", t. 6, nr 29, s. 849-866.

Bolino M.C., Klotz A.C., Turnley W.H., Harvey J. (2013), Exploring the dark side of organizational citizenship behawior, „Journal of Organizational Behavior”, nr 34, s. 542-559.

Bolino M.C., Turnley W.H., Gilstrap J.B., Suazo M.M. (2010), Citizenship under pressure: What's a "good soldier" to do?, „Journal of Organizational Behavior", $\mathrm{nr}$ 31, s. 835-855. 
Bommer W.H., Miles E.W., Grover S.L. (2003), Does one good turn deserve another? Coworker influences on employee citizenship, „Journal of Organizational Behavior”, $\mathrm{nr}$ 24, s. 181-196.

Britt T.W., McKibben E.S., Greene Shortridge T. M., Odle Dusseau H.N., Herleman H.A. (2012), Selfengagement moderates the mediated relationship between organizational constraints and organizational citizenship behaviors via rated leadership, „Journal of Applied Social Psychology", t. 8, nr 42, s. 1830-1846.

Chen Ch.V., Tang Y.Y., Wang S.J. (2009), Interdependence and organizational citizenship behavior: exploring the mediating effect of group cohesion in multilevel analysis, „The Journal of Psychology", t. 6, nr 143, s. 625-640.

Chwalibóg E. (2013), Wyzwalanie zachowań obywatelskich pracowników jako krok w dążeniu do doskonałości organizacji, „Prace Naukowe Uniwersytetu Ekonomicznego we Wrocławiu. Management Forum", nr 322, s. 18-28.

Cialdini R.B. (2013), Wywieranie wpływu na ludzi, Gdańskie Wydawnictwo Psychologiczne, Gdańsk.

Cohen A. (2006), The relationship between multiple commitments and organizational citizenship behavior in Arab and Jewish culture, „Journal of Vocational Behavior”, t. 1, nr 69, s. 105-118.

Cohen A., Vigoda E. (2000), Do good citizens make good organizational citizens? An empirical examination of the relationship between general citizenship and organizational citizenship behavior in Israel, „Administration \& Society”, t. 5, nr 32, s. 596-624.

Cropanzano R., Mitchell M. S. (2005), Social exchange theory: An interdisciplinary review, "Journal of Management", t. 6, nr 31, s. 874-900.

Fassina N.E., Jones D.A., Uggerslev K.L. (2008), Meta-analytic tests of relationships between organizational justice and citizenship behavior: testing agent-system and Shared-Variance Models, „Journal of Organizational Behavior”, nr 29, s. 805-828.

Fenney C. (2012), Managing and Communicating across the Generations, http://sbr.com.sg/hr-education/commentary/managing-and-communicating-across-generations (dostęp: 27.07.2018).

Fowler J.G. (2013), Customer citizenship behavior: an expanded theoretical understanding, „International Journal of Business and Social Science", t. 5, nr 4, s. 1-8.

Glińska-Neweś A., Lis A. (2016), Paradoks wspótwystępowania organizacyjnych zachowań obywatelskich i kontrproduktywnych, „Prace Naukowe Uniwersytetu Ekonomicznego we Wrocławiu", nr 422, s. 265-274.

Gore J.S., Kiefner A.E., Combs K.M. (2012), Personality traits that predict academic citizenship behavior, ,Journal of Applied Social Psychology”, t. 10, nr 42, s. 2433-2456.

Grant A.M., Mayer D.M. (2009), Good soldiers and good actors: prosocial and impression management motives as interactive predictors of affiliative citizenship behaviors, „Journal of Applied Psychology", nr 94, s. 900-912.

Greguras G.J., Diefendorff J.M. (2010), Why does proactive personality predict employee life satisfaction and work behaviors? A Field Investigation of The Mediating Role of The Self-Concordance Model, „Personnel Psychology”, nr 63, s. 539-560.

Kostera M. (2003), Antropologia organizacji. Metodologia badań terenowych, Wydawnictwo Naukowe PWN, Warszawa.

Lewicka D., Wiernek B. (2004), Psychologia w pracy menedżera, Akademia Górniczo-Hutnicza. Uczelniane Wydawnictwa Naukowo-Dydaktyczne, Kraków.

Lin Ch.P., Lyau N.M., Tsai Y.H., Chen W.Y., Chiu Ch.K. (2010), Modeling corporate citizenship and its relationship with organizational citizenship behaviors, „Journal of Business Ethics”, nr 95, s. 357-372.

Organ D. W., Podsakoff P. M., MacKenzie S.B. (2006), Organizational citizenship behavior: its nature, antecedents, and consequences, Sage Publications, Thousand Oaks. 
Podsakoff N.P., Whiting S. W., Podsakoff P. M., Blume B.D. (2009), Individual-and organizational-level consequences of organizational citizenship behaviors: A meta-analysis, „Journal of Applied Psychology", nr 94, s. 122-141.

Punjaisri K., Wilson A. (2007), The role of internal branding in delivery of employee brand promise, „Brand Management”, t. 1, nr 15, s. 57-70.

Robbins S., Judge T. (2011), Organizational Behavior, Pearson, New York.

Rusak P. (2013), X, Y, Z: pokoleniowa bitwa biurowa, „Przewodnik Pracodawcy 2013/2014”, s. $10-12$.

Ryan R.M., Deci E.L. (2000), Self-Determination Theory and the Facilitation of Intrinsic Motivation, Social Development, and Well-Being, „American Psychologist”, t. 1, nr 55, s. 68-78.

Snell R.S., Wong Y.L. (2007), Differentiating good soldiers from good actors, „Journal of Management Studies", nr 44, s. 883-909.

Spence J.R., Ferris D.L., Brown D.J., Heller D. (2011), Understanding daily citizenship behaviors: A social comparison perspective, ,Journal of Organizational Behavior”, $\mathrm{nr} 32$, s. 547-571.

Turek D. (2013), Rola zachowań obywatelskich w kreowaniu wewnętrznego wizerunku pracodaw$c y$, ,Edukacja Ekonomistów i Menedżerów”, nr 30(4), s. 25-39.

Turek D., Czaplińska I. (2014), Praktyki ZZL, klimat organizacyjny i postrzeganie wsparcia menedżerskiego a zachowania obywatelskie pracowników, „Organizacja i Kierowanie”, nr 4(164), s. $115-140$.

Van Dyne L., Ellis J.B. (2004), Job creep: a reactance theory perspective on organizational citizenship behavior as overfulfillment of obligations, [w:] J.A.M. Coyle Shapiro, L. M. Shore, M.S. Taylor, L.E. Tetrick (red.), The Employment relationship: examining psychological and contextual perspectives, Oxford University Press, Oxford.

Van Dyne L., LePine J.A. (1998), Helping and voice extra-role behaviors: evidence of construct and predictive validity, „Academy of Management Journal”, $\mathrm{nr} 41$, s. 108-119.

Vigoda-Gadot E. (2006), Compulsory citizenship behavior: theorizing some dark sides of the good soldier syndrome in organizations, „Journal for the Theory of Social Behaviour”, nr 36, s. 77-93.

Whiting S. W., Podsakoff P. M., Pierce J.R. (2008), Effects of task performance, helping, voice, and organizational loyalty on performance appraisal ratings, ,Journal of Applied Psychology”, nr 93, s. 125-139.

Yun S., Takeuchi R., Liu W. (2007), Employee self enhancement motives and job performance behaviors: investigating the moderating effects of employee role ambiguity and managerial perceptions of employee commitment, ,Journal of Applied Psychology”, nr 92, s. 745-756. 


\title{
Motives for Undertaking Organizational Citizenship Behaviors by Differentiated Generations of Employees
}

\begin{abstract}
The issue of undertaking organizational citizenship behavior (OCB) in enterprises, due to their wide and positive impact on many aspects of organizational activity, remains in the area of interest of management theorists and practitioners. These behaviors, due to the fact that they go beyond the formal professional role of employees, affect the quality of work performed, financial efficiency, improve the atmosphere at work, stimulate the development of innovative competences and behaviors, and customer satisfaction. However, the determinants and conditions in which employees work for the benefit of the organization, without expecting remuneration, are not fully identified. The purpose of this study is therefore to identify and analyze the motives for undertaking organizational citizenship behaviors by representatives of employee groups of different generations. The exploratory nature of the problem determined the adoption of qualitative approach. The study used the case study method and, within it, partly structured interviews and analysis of company documents.
\end{abstract}

Keywords: organizational citizenship behaviors, generations of employees

JEL: M14

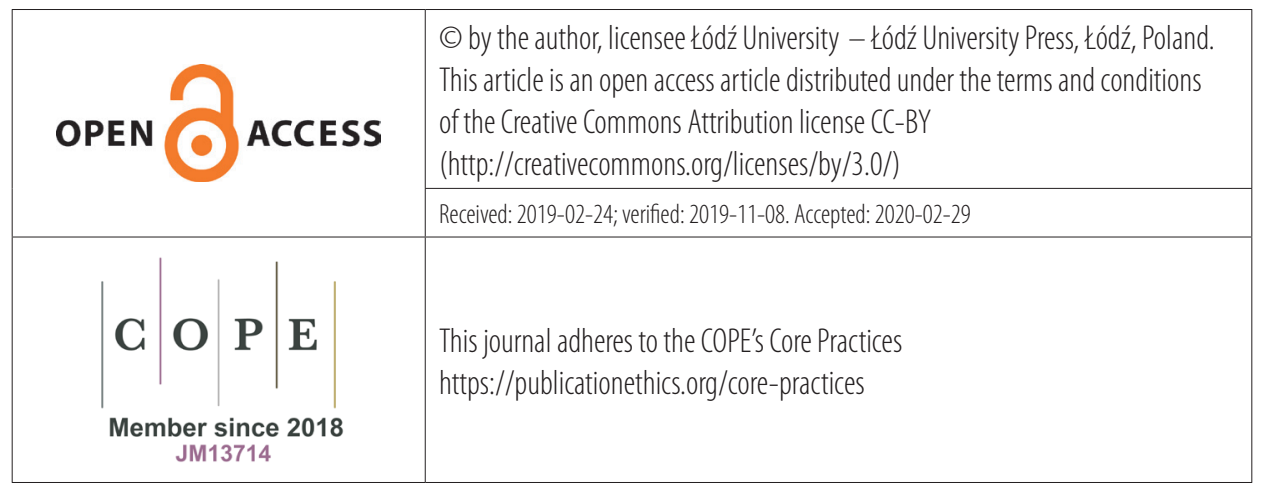

